\title{
Cross-sectional Study on Traditional Pork Rearing Practices and Cysticercosis in the South Part of Ivory Coast
}

\section{Koffi Kouassi Eugène}

Institut Pasteur de Cote d'Ivoire

Soumahoro Man-Koumba

Institut Pasteur de Cote d'Ivoire

Boka O. Marcel

Ministère de l'élevage , Abidjan

Melki Jihen

Institut Pasteur de Cote d'Ivoire

Ndri Borel

Institut Pasteur de Cote d'Ivoire

Touré 0 . André

Institut Pasteur de Cote d'Ivoire

Djaman A. Joseph

Institut Pasteur de Cote d'Ivoire

N'goran K. Elieser

Universite Felix Houphouet-Boigny Unite de Formation et de Recherche Biosciences

Ronan Jambou ( $\nabla$ rjambou@pasteur.fr)

Institut Pasteur de Côte d'Ivoire, Abidjan, Global Health Departments, Institut Pasteur Paris, France https://orcid.org/0000-0002-9908-1378

\section{Research article}

Keywords: pigs, Côte d'Ivoire, cysticercosis, livestock

Posted Date: August 24th, 2020

DOI: https://doi.org/10.21203/rs.3.rs-61748/v1

License: (c) (i) This work is licensed under a Creative Commons Attribution 4.0 International License.

Read Full License 


\section{Abstract}

In West africa, pig meat know as pork is often supplied by traditional farms in rural areas. This pratice causes important sanitary risk by lack of veterinary control of farms and slaughterhouses in rural areas. The objective of this study was to describe pig husbandry practices used in southern Côte d'Ivoire in order to establish a surveillance system for cysticercosis disease. This survey was carried out among traditional pig breeders living in villages of the district of Dabou, Aboisso and Agboville. The data collected focused on the profile of producers and on the characteristics of the farms. A total of 321 breeders have been identified (Dabou 72 (22.4\%), Aboisso 26 (8.1\%) and Agboville 223 (69.5\%)). Most of the herders were male (87.8\%). A total of 3663 heads of pigs were counted with a majority of young pigs $(60.2 \%)$ and females $(29.3 \%)$ for $10.5 \%$ of male breeders. The local race was predominant $(80.6 \%)$ for

only $15.5 \%$ of half-caste races. Most of the farms used permanent divagation rearing (53.3\%). Following investigation of the herds, pigs were randomly samples in all the villages of the three areas using quota methods. Animals were blood sampled and serums were analyzed using Ac-ELISA and Western Blot. Among 639 animals selected, $13,20 \%$ had antibodies against cysticercosis with large variations from one village to another. The study highlights that, in this region, pig farming remains essentially traditional, with free grazing of animals which constitutes a major sanitary risk especially for Taenia solium.

\section{Introduction}

In 2013 , the pig livestock in Ivory Coast was estimated to be 362,693 head with 80,867 modern pigs (imported breed) and 281,826 local pigs [1]. This breeding constitutes an important source of animal protein for the Ivorian population. However, the annual national consumption of pig reaches 66448 tones with $85.6 \%$ of imported products for only $14.4 \%$ from national production [2]. This highlights the market opportunities sustaining local initiatives. However, the national market is provided by a great diversity of farming practices (traditional, semi-industrial and industrial), for which data on pork food safetyare missing. Indeed, $93 \%$ of national pig production is not subject to official slaughter and therefore to veterinary control [1]. The southern zone of Ivory Coast provides most of the market of the economic capital Abidjan. Commercial paths/flows are very short and butchers or consumers usually acquire pork through informal agreement with villagers living the small towns surrounding Abidjan. Studies are therefore urgently needed to specify the location and the typology of the farms to better organize this control.

In tropical countries, the control of pork (pig meat) can target lot of microorganisms among with parasites. Indeed, cysticercosis is widely spread in African countries due to poor food safety and sanitation organization in the local farms [3]. Cysticercosis is due to the larvae of the Taenia solium. Humans are the definitive host of this tapeworm, but pigs are the intermediate host which are contaminated by eggs in human stools. High prevalence of human and pig cysticercosis is usually associated with a higher risk of human contamination by eggs, leading to human cysticercosis, and mostly epilepsy. Cysticercosis has thus of both public health and economic importance. 
The aim of this study was to create a detailed map of the pig population in these regions including typology of the farms to set up a "home based" veterinary control. To describe farming practices, an exhaustive field survey was conducted in the three districts of Dabou, Aboisso and Agboville. This study was also the first opportunity to provide preliminary data on porcine cysticercosis in this region.

\section{Materials And Methods}

\subsection{Practice investigation}

The survey was conducted from June 2016 to August 2017, in southern Côte d'Ivoire, in the administrative areas of Dabou, Agboville and Aboisso. These areas provide most of the animals attending the main slaughterhouse of Abidjan. These are also the areas from where most of the meat is condemned and disposed of as inedible due to cysticercosis, echinococcosis, etc. The exhaustive list of the villages surrounding the three selected cities was obtained from the National Study Bureau (BNET). For each village, pig herds were investigated. A first visit was carried out in each village to contact authorities and to identify villages rearing pigs. The survey population consisted of hog producers questioning about i) the profile of the family and ii) the characteristics of their farms.

\subsection{Epidemiological study}

The number of pigs to be sampled for the serology analysis was calculated to obtain a confident interval of $4 \%$ with a power of $80 \%$ and an estimated prevalence of cysticercosis at $50 \%$. An extra effective of pig of $5 \%$ was added, which lead to a population of 600 pigs to investigate in the three districts. Following exhaustive investigation of the pig population in the three areas, random sampling of herds was conducted using quota strategy. In each district the number of pigs to be sampled was calculated according to the proportion of the district in the total population of pigs. For each district, the number of pigs to be sampled in each village was calculated according to the proportion of the pig population village in the total population of pigs of the district. All the villages with more than ten pigs were considered for sampling. In each village, pigs were considered to belong to the same herd and were randomly sampled to constitute one grape of animals. After informed consent of the breeders, selected pigs more than three months old were blood sampled. GPS location of each herd was registered using Garmin device. A specific questionnaire was documented for each herd and each animal on each herd. Blood samples were kept at $4{ }^{\circ} \mathrm{C}$ until treatment at the laboratory.

\subsection{Cysticercosis serology}

Detection of antibodies against cysticercosis was conducted using the Tsang et a/ glycosylated fraction of the cyst [4]. Sera were first used in ELISA ( $\operatorname{lgG}$ ) and positive ones were secondary analysed using western blot (IgG). (detailed protocol is available on www.protocols.iso xxxx). Negative controls used to define the threshold of positivity were sera from piglets from industrial herd. For this study, positive serology for cysticercosis was defined as positive in ELISA and positive in Western Blot. Presence of at least two bands among P6-8, P12, P23-26, P39, P45 was used to define positive western blot [5]. P50-55 
band was not considered during this study as supposed to harbored cross-reactivity with $T$ hydatigena a pig tapeworm [6].

\subsection{Data analysis}

The data were entered in the Epidata 3.1 software and then analyzed using STATA version 11 software. Qualitative variables were compared with the Chi2 test or the Fisher exact test where appropriate. Quantitative variables were compared with the Kruskal-Wallis test.

\section{Results}

\subsection{General profile of the breeders}

A total of 321 breeders were recorded, including 72 (22.4\%) in Dabou, 26 (8.1\%) in Aboisso and 223 (69.5\%) in Agboville (Table I), located in 51 villages (9 in Dabou, 16 in Aboisso and 26 in Agboville, Fig. 1). The spread of these breeders in the villages is not homogenous. It ranges for zero to 35 inducing putative focus of diseases. Most of the producers were men $(84.7 \%, 96.1 \%$ and $87.9 \%$ of the breeders in the three regions respectively). The average size of the family varies from $6.4 \pm 3$ to $10.5 \pm 9$ persons per household (Table I). Surprisingly in Agboville and Dabou some $26.9 \%$ and $2.7 \%$ respectively of the breeders were single.

The size of herders' households and the size of farms in different localities are slightly correlated $(r=0.3$, $p<0.0001$ ). The livestock size increases slightly with the size of the farmer's household. (Fig. 1).

The median size of breeding is independent of the gender of the farmer in the localities $(p=0,16)$. Likewise, there is no observed relationship between gender of the famer and race of pig $(p=0,67)$. However, female breeders were more likely than males to practice permanent wandering $(69.2 \%$ vs. $51.1 \%$, $p=0.033)$.

The median size of breeding is independent of the race of pig across all departments $(p=0,60)$. However, the median size of breeding is dependent of the pig race in Agboville $(p=0.042)$.

\subsection{Characteristics of the farms}

Out of 3,663 hogs registered, Agboville farms hold 2,537 heads (69.2\%), while Dabou and Aboisso hold $713(19.4 \%)$ and $413(11.2 \%)$ respectively. The livestock is more important in Agboville than in the other localities, but the average herd size was higher in Aboisso $(p=0.002)$ (Table 1). The composition of pig farms shows a high proportion $(p<0.001)$ of young pigs $(60.2 \%$, Dabou $53.7 \%$, Aboisso $58.9 \%$ and Agboville 62.3\%) compared to reproductive female (29.3\%) and male (10.5\%) (Table I). The Median number of pigs by breeding is 5 (3-10), 12 (8-20), 9 (4-16) in Dabou, Aboisso and Agboville Respectively. This number is statistically lower at Aboisso $(p=0.001)$.

In Dabou, the smallest farm holds 59 pigs and the biggest one holds 353 pigs. Most of the animals are piglets (Table I), and females are more frequent than males. Half of the herds do not contain males and 
sex ratio (male/female) varies with the district $1 \frac{1}{2}, 1 / 4,1 / 3$ at Dabou, Aboisso and Agboville, respectively.

The main breed of pigs reared in these localities is the local one (81.3\%), especially in Agboville (95.2\%, p $<0.001$ ), which is representative of the traditional farming mode. In parallel to these local breeds, mixed races were found in the three areas accounting for $16.2 \%$ of the animals (Table I). In Dabou, mixed race is more prevalent, as well as pens $(p<0.001$, Table I). Whereas in other localities (Aboisso, Agboville) almost all the farms practice permanent wandering. There is a clear correlation between the size of the herd and of the household (Fig. 2)

\subsection{Seroprevalence of pig cysticercosis}

For the three districts a total of 3,628 pigs was found with 713 in Dabou, 378 in Aboisso and 2537 in Agboville, leading to a sampling size of 197, 160 and 243 animals in these three districts, respectively. A total of 659 of pigs were included with 203 in Dabou, 271 in Agboville, 185 in Aboisso (Table II). Among these animals, 224 were positive with antibodies against cysticercosis in ELISA (37.9\%): 74 (38.1\%) in Dabou, 47 (17.6\%) in Agboville and 103 (58.1\%) in Aboisso. Aboisso harbored the highest prevalence with more than half of the animals contaminated $(p<0.05)$. Indeed, among Elisa positive serums, only 83 were positive with western blot. The final seroprevalence was thus $13.20 \%$ with de $20.7 \% ; 7.9 \% ; 13.1 \%$ in Dabou, Agboville and Aboisso respectively (Table II, significant difference $p=0.0008$ ). However, the prevalence of antibody against cysticercosis varies from one herd to another (Fig. 3) peacking to more than $40 \%$ in some herds. Geographical association of herds with high prevalence of cysticercosis can also observed in some districts (Fig. 3).

\section{Discussion}

The high number of men shows that in Côte d'Ivoire this economic activity remains reserved to them unlike other countries where pig gathering is devoted to women and children. This had already been pointed out by Tra [7] in the Abidjan region, in Cameroon and in Central African Republic [8]. In these last countries, livestock is exclusively raised by men while women tend to raise poultry [9]. On the opposite side, in the groundnut basin, this activity seems to be dominated by women valuing grains [8]. In these regions, women preparing traditional beers and alcohol sell the seeds to the farmers against piglets. This allows them to rear small domestic livestock, which are fill with seeds [10].

The larger number of herds at Agboville is first related to its larger population with 100 villages spread over $3,850 \mathrm{~km}^{2}$. In this area, animals are wandered and feed on household dumps. In Dabou, the low number of pigs can be related to different eating habits, as the Adioukrou people are lagoon people practicing mainly fishing and eating fishes. To date this area is also widely open to the Abidjan megapole and breeding activities decrease drastically in parallel with the increase of commercial ones. Similarly, in the Aboisso area, the low number of pigs recorded could be related to a predominant agricultural activity (cocoa, coffee, oil palm and rubber crops) of the villagers, sustained by a ferritic type of soil with good water retention, heavy vegetation, and dense hydromorphic forests [11]. In this region, pig farming would 
be traditionally prohibited because of the destruction of crops and of the spread of garbage by these animals. In the same line, free range farming is now limited by the extension of cultivated and of urban areas [12]. Accordingly, when the number of breeders decreased in villages, the number of animals increased. However, data obtained during this study are far from the number of farmers and livestock registered by the Association of Pork Producers of Ivory Coast [13]. In this report, only 58 breeders were registered in the Dabou district for 4,571 pigs (an average of 79 animals / breeder). Despite the time elapsed since this report, this difference could be explained by the design of our study focusing on traditional farms. These traditional breeding are mostly conducted on a rambling path, which does not allow accurate census of breeders and animals. In the same line, since May 1996, the swine population undergoes regular African Swine Fever epidemics (ASF) which impact more deeply the production of "modern" pigs (64\% of decline) than of traditional pigs (32\%) [14]. Since then, the Ivorian pork sector has been subject to fierce competition from imported pork and other pig products [13].

In this study, the increase in livestock size with the size of the farmer's household would mean that the large number of people in the household would constitute the labour force.

The female breeders were more likely than males to practice permanent wandering, because they are more involved in household activities and food crops. They have no more time for enclosure breeding.

The high proportion of the young pigs is an indicator of good prolificacy of sows, but still lower than in neighboring countries such as Senegal (range of 7.17) [15] or Cameroon (range of 12.4) [8]. The proportion of boars remains low in the three areas studied with $15 \%, 13 \%$ and $8.7 \%$ of the herd. This could be due to a quick reform of the males, sold and slaughtered during the holidays and festivities. This has also been observed in Senegal [16], Central Africa [17] and Benin [18]. For these authors, the low proportion of males would be an indicator of the traditional rearing pattern of local pigs. No significant difference is observed for the proportion of females according to the areas (male/female ratio 1/2 in Dabou, 1/4 in Aboisso and 1/3 in Agboville), whereas it increases around Abidjan with a male/female ratio at $1 / 8$ [13] and even to $1 / 10$ [7]. This is characteristic of an uncontrolled reproduction associated with wandering. However, this high number of males per female could reduce consanguinity.

The high number of the local breed observed in this study is in accordance with data from Cameroon where local breed accounted for $95 \%$ of the population [8], or from Madagascar [19]. Local breeds cover a wide variety of lineages with heterogeneous performances. These more rustic animals are more adaptable to difficult food and climatic conditions [7], but they grow slowly and hardly reach $50 \mathrm{~kg}$ for adults. Their average daily gain (ADG) is greater than $400 \mathrm{~g} /$ day with a consumption index equal to 4 for weights between 20 and $60 \mathrm{~kg}$ [20]. From one country to another, these local breeds show large variations in the age of first farrowing, ranging from 16.5 months in Senegal [21] to only 11.3 months in the Central African Republic [17]. Local breeds are diverse depending on the country: the Black Spotted Spotted Black and the Black Criollo with long bristles in Latin America, the Bakosi in Cameroon, and the Korhogo in Ivory Coast, the Ghanaian Ashanti in Ghana, and the Windsnyer on the back sharp and Kolbrock in South Africa [7]. They have a head with a short forehead, an elongated snout and small ears carried horizontally 
or slightly erect. A narrow body is carried by fairly long limbs with a tourniquet size ranging from 40 to 60 centimeters. The skin is black, sometimes magpie, rarely white with a coat of silk more or less long and coarse [22].

Overall, the proportion of mixed breeds is higher in Dabou $(54,1 \%)$ than other areas. It is the same proportion observed in Bangui (52\%) [8], due to the system of stray farms where the projections are not controlled. Mixed-breed animals originated mostly from crossbreeds of local breeds and imported European and North American ones (Large White, Landrace, Duroc, Pietrain, Hampshire) or between local breeds and breeds of these crosses [23]. These animals are more vigorous and more resistant than those of the parental exotic breed, but with better performance than local breeds [17]. According to the Interprofessional Fund for Agricultural Research (FIRCA), in Ivorian flocks, pigs with improved zootechnical performances can be also found. These performances are $100.75 \mathrm{~kg}$ of live weight at 7 months, with an average daily gain (GMQ) of $806.2 \mathrm{~g} /$ day for Large White, and $108.9 \mathrm{~kg}$ of live weight (GMQ) with a gain of (GMQ) of $821.66 \mathrm{~g} /$ day for the Landrace.

The predominant pens farms observed in Dabou belong to employees of industrial palm and rubber cooperatives. These cooperatives are at the origin of rearing in pens, as it is supposed to increase productivity, reduce damage caused by stray animals, reduce the spread of diseases, and avoid conflicts between farmers causing administrative fines [25]. In Ivory Coast, for farms in confinement, the breeding is controlled by the breeder. Boars used for this purpose are either borrowed from other farms or purchased [25]. The origin of boars is rarely known including multiple crosses which increases the risk for consanguinity [26]. Unlike Dabou, the other localities practice the permanent system. In this system, projections are uncontrolled, and it is observed early increasing consanguinity [26]. The farrowing is done in the nature, next to the compound, or rarely in the enclosure. This system is the cheapest and the easiest for the farmers but it exposes animals to massive infestations and various pathologies leading to high mortality, slow growth and low productivity [22].

The result of seroprevalence of pig cysticercosis shows a highest prevalence observed in Aboisso with anibodies against cysticercosis in ELISA. This rate is quite high according to Druet [27] who collected data in sub-Saharian countries with prevalence ranging from 0, 23 and $24,0 \%$. Using the same technic, a similar rate of $38 \%$ was reported by Zoli [28] in the Ménoua region and by Nguekam [29] (21, 78\%). However, a lack of specificity was describe for ELSIA due to cross reactivity with other helminthes.

The final seroprevalence obtained with Western Blot shows a significant difference in the localities. This difference of seropositivity was recently related to cross-reactivity with other Taeniidae as Taenia hydatigena [30]. Large variation of cysticercosis seroprevalence can be observed from one village to another (Fig. 1). However, this prevalence is higher than that reported by Geerts [3] in slaughterhouses in Abidjan by visual inspections of the carcasses. Visual inspection is much less sensitive than serology and highly dependent on technical competence of the user [32].

\section{Conclusion}


The aim of this study was to estimate the pig population in three districts of the southern region of the country (Aboisso, Agboville and Dabou) and to characterize the breeding system in these areas. This region is the main origin of the pig meat (pork) in Abidjan. In this region livestock is modest and pig farming is conducted mainly by men. The rearing modes were mainly permanent wandering and rarely permanent confinement. However, this situation is associated with an overall moderate cysticercosis seroprevalence which can peak to more than $40 \%$ in some village. Lack of slaughterhouses and veterinarians in rural area lead to prevalent home slaughtering which concern an estimate $93 \%$ of pork in Ivory Coast. These rearing practices expose thus to significant health risks for the Abidjan population. However, the small size of the herds could be an opportunity to propose permanent confinement as new practice, especially if women can be involved in this activity to provide food by valuing kitchen waste.

\section{Declarations}

\section{Ethics approval and consent to participate}

Due to lake of national animal ethic committee, the study was submitted and approved by the Ministry of Agriculture. It was conducted on behalf of the Direction des services vétérinaires., with teams from this Ministry. Client-owned animals gave they informed consent for the study and supervised sampling of their herd.

\section{Availability of data and materials}

Data are covered by administrative approval. They can be obtained from the authors through reasonable requests.

\section{Competing interests}

The authors declare no conflict of interest.

\section{Funding}

This work is supported by a grant from the PASRES program (Swiss Cooperation) and Pasteurlnnov program (Institute Pasteur, Paris)

\section{Authors' contributions}

KKE is conducted field and laboratory studies and drafted the manuscript,

MKS supervised epidemiological protocol and analysis,

BM supervised epidemiological protocol and participated in field studies

participated in laboratory studies and standardized in vitro model,

$\mathrm{MJ}$ and NB conducted serological investigation 
KA standardized in vitro model and review the manuscript,

OAT, DAJ and NKE reviewed the manuscript, and participated to the design of the study

RJ coordinated the project, conducted statistical analysis and wrote the manuscript

\section{Acknowledgments}

We would like to thank all the producers of pigs, the field investigators (ANADER and Veterinary Services) of Dabou, Aboisso and Agboville for allowing us to lead the investigation. We also thank the entire EpiCysti team of IPCI for its technical support. We would like to thank Dr Serge AGBO for his review of the document.

\section{Consent to publish}

All the authors read the last version of the text and agreed for publication.

\section{References}

1. Miparh., Annuaire des statistiques des ressources animales et halieutiques Côte d'Ivoire, 2013, 35P.

2. Miparh,. Annuaire des statistiques des ressources animales et halieutiques Côte d'Ivoire, 2015, 29P.

3. Geerts S, Zoli A, Willingham L, Brandt J, Dorny P, Preux PM. Taenia solium cysticercosis in Africa: an under-recognised problem. In: Craig P, Pawlowski Z, editors. Cestode zoonoses: echinococcosis and cysticercosis an emergent and global problem. Amsterdam: eds., IOS Press; 2002. p. 395.

4. Tsang VC, Brand JA, Boyer AE. An enzyme-linked immunoelectrotransfer blot assay and glycoprotein antigens for diagnosing human cysticercosis (Taenia solium). The Journal of infectious diseases. 1989;159:50-9.

5. Michelet L., Le complexe taeniase/cysticercose, la phylogénie et l'évolution de Taeniasolium et la biologie moléculaire appliquée au diagnostic. Thèse de Doctorat de Sante publique et épidémiologie, Université de Limoges, France, 2010.

6. 10.4269/ajtmh.17-0378

Muro C, Gomez-Puerta LA2, Flecker RH3, Gamboa R, Barreto PV1, Dorny P, Tsang VCW5, Gilman RH6, Gonzalez A.E2., Garcia H.H7,1.,, O'Neal SE, For The Cysticercosis Working Group In Peru. Porcine Cysticercosis: Possible Cross-Reactivity of Taenia hydatigena to GP50 Antigen in the Enzyme-Linked Immunoelectrotransfer Blot Assay. Am J Trop Med Hyg. (2017) doi: 10.4269/ajtmh.17-0378.

7. Tra B, Filière porcine en Côte d'Ivoire, Production, propositions d'amélioration et perspectives de développement. Thèse de Médecine Vétérinaire, Ecole Inter Etats des Sciences et Medecine Vétérinaire de Dakar/ Sénégal,2009.

8. Mopate LY, Koussou MO, Nguertoum EA, Ngo TAC, Lakouetene T, Awa DN, Mal MHE, Caractéristiques et performances des élevages porcins urbains et périurbains des savanes d'Afrique centrale: cas des villes de Garoua, Pala et Bangui. Savanes africaines en développement. Montpellier: CIRAD, 2010, 9p. 
9. Oussou., Rôle des éleveurs de caprins dans l'émergence des maladies caprines (Capra hircus, schaller, 1977) dans la localité de Beoumi (Côte d'Ivoire). J. Appl. Biosciences (2017).

10. Mopate LY. Dynamique des élevages porcins et amélioration de la production en zones urbaine et périurbaine de N'Djaména (Tchad). Thèse de Doctorat Unique, Gestion intégrée des ressources naturelles (GIRN), option, Productions animales, Université polytechnique de Bobo-Dioulasso (UPB), Burkina Faso,2008.

11. Koua A., Situation de la production de café en côte d'ivoire,cas du département d'Aboisso, état des lieux et perspectives. Mémoire d'Ingénieur Agronome, option agroéconomie, École Supérieure d'Agronomie de Yamoussoukro,2007.

12. Mavouenzela D, Anglade K, Dourou B, Foutou G, Bamona R. Étude sur la filière porc dans le Département. Congo: de Pointe Noire; 2014. 43P.

13. Apporci., Les difficultés de la filière porcine ivoirienne face aux importations massives de produits porcins: Rapport. - Abidjan : APPORCl,2004, 5 p.

14. Miparh. Programme d'appui à la redynamisation de la filière porcine. - Abidjan: SIVAC; 2006. 22 p.

15. ${ }^{15}$ Sambou G. Analyse des impacts de la décharge de Mbeubeus (Dakar) sur les élevages porcins environnants. Thèse de Médecine Vétérinaire, Ecole Inter Etats des Sciences et Medecine Vétérinaire de Dakar/ Sénégal,2008.

16. Missohou A, Niang M, Foucher $H$, Dieye PN. Les systèmes d'élevage porcin en Basse Casamance (Sénégal). Cahiers Agricultures. 2001;10(6):405-8.

17. Abdallah $E$, Élevage porcin en région périurbaine de Bangui/Centrafrique. Thèse de Médecine Vétérinaire, Ecole Inter Etats des Sciences et Medecine Vétérinaire de Dakar/ Sénégal,1997.

18. Deka E, Chrysostome C, Nonfon WR, Amélioration de la productivité du porc local au sud Bénin: rapport II Atelier de restitution des résultats de recherche sur le porc local aux différents acteurs de la filière porc. - UAC : FSA/CRDPL,1998, $62 \mathrm{p}$.

19. ${ }^{19}$ Humbert C. Etude épidémiologique de la Peste Porcine Africaine dans la region de Marovoay (Madagascar). Mémoire de Certificat d'Etude Approfondie Vétérinaire, Pathologies animales en région chaude, ENV Toulouse,2006.

20. Serres H. Précis d'élevage du porc en zone tropicale. - Ministère Français de la Coopération et du Développement. - Paris: manuel et précis d'élevage,1989, 331 p.

21. Buldgen A, Piraux M, Dieng A, Schmit G, Compere R. Les élevages de porcs traditionnels du bassin arachidier sénégalais. Revue Mondiale de Zootechnie (1994). 80/81, 3-4: 63-70.

22. Holnes DH. Le porc. Paris: Maison neuve et Larose ; ACCT- CTA; 1994. 217 p.

23. Lukusa BD, Amélioration de la pratique d'élevage de porcs dans les milieux urbains et périurbains de la ville de Kinshasa. Mémoire de Diplôme d'Études Spécialisées en Gestion des Ressources Animales et Végétales en Milieux Tropicaux, Faculté Universitaire des Sciences Agronomiques de Gembloux, 2005. 
24. Youssao AKI, Koutinhouin GB, Kpodekon TM, Bonou AG, Adjakpa A, Dotcho CDG, Atodjinou FTR. Production porcine et ressources génétiques locales en zone périurbaine de Cotonou et d'AbomeyCalavi au Bénin. Revue d'Élevage et de Médecine vétérinaire des Pays tropicaux (2008) 61: 235-243.

25. ${ }^{25}$ Nonfon WR. Amélioration de sa productivité par l'alimentation. Thèse de Doctorat en Sciences agronomiques et Ingénierie biologique, Faculté Universitaire des Sciences Agronomiques de Gembloux, Belgique,2005.

26. ${ }^{26}$ Agbokounou AM. Étude des besoins énergétiques et protéiques du porc local béninois en phase de démarrage croissance. Mémoire de DEA, Sciences agronomiques et Ingénierie biologique, Orientation élevage, Faculté Universitaire des Sciences Agronomiques de Gembloux, Belgique,2001.

27. Druet CM, Ramanankandrasana B, Bisser S, Dongmo L, Avode G, Nzisabira L. Taenia solium Cysticercosis in Africa. Taenia Solium Cysticercosis: From Basic to Clinical Science (2002)129.

28. Zoli A, Geerts S, Vervoort T. An important focus of human andporcine cysticercosis in WestCameroun. In "Current topics in Veterinary Medicine and Animal Science". (Helminth Zoonoses) Ed. Geerts et al,1987, p. 85-91.

29. ${ }^{29}$ Nguekam JP. La Cysticercose Porcine dans les Departements de la Mifi et des Bamboutos. Master of Science Thesis, Institut de la Médicine Tropicale, Anvers-Belgique,1998.

30. Mandal J, Singhi PD, Khandelwal N, Malla N. Evaluation of ELISA and dot blots for the serodiagnosis of neurocysticercosis, in children found to have single or multiple enhancing lesions in computerized tomographic scans of the brain. Ann Trop Med Parasitol. 2006;100:39-48.

31. Mishra GS, N'Depo AE. Les cysticerques des animaux abattus a l'abattoir de Port-Bouet (Abidjan), (Cote d'Ivoire). Rev Elev Med vet Pays trop. 1978;31(4):431-6.

32. Goussanou S, Kpodekon T, Saegerman C, Azagoun E, Youssao A, Farougou S, Praet N, Gabriël S, Dorny P. Korsak Koulagenko N., Spatial distribution and risks factors of porcine cysticercosis in southern Benin based meat inspection records. International Research Journal of Microbiology. 2013;4(8):188-96.

\section{Tables}

Table I. Characteristics of the breeders and of the herds in the three districts of Dabou, Aboisso and Agboville 


\begin{tabular}{|c|c|c|c|c|c|c|}
\hline & & $\begin{array}{l}\text { Dabou } \\
\text { n(\%) }\end{array}$ & $\begin{array}{l}\text { Aboisso } \\
\text { n (\%) }\end{array}$ & $\begin{array}{l}\text { Agboville } \\
\text { n (\%) }\end{array}$ & $\begin{array}{l}\text { Total } \\
\text { n (\%) }\end{array}$ & $\begin{array}{l}\text { P } \\
\text { (Chi2 } \\
\text { test) }\end{array}$ \\
\hline \multirow[t]{3}{*}{ Breeders } & Male & $\begin{array}{l}61 \\
(84,7)\end{array}$ & $25(96,1)$ & $\begin{array}{l}196 \\
(87,9)\end{array}$ & $\begin{array}{l}282 \\
(87,8)\end{array}$ & $0.33^{*}$ \\
\hline & Female & $\begin{array}{l}11 \\
(15,3)\end{array}$ & $1(3,9)$ & $27(12,1)$ & $39(12,2)$ & \\
\hline & Total & 72 & 26 & 223 & 321 & \\
\hline \multicolumn{2}{|c|}{$\begin{array}{l}\text { Mean number of persons in the } \\
\text { breeders' family }(\mathrm{m} \pm \mathrm{SD})\end{array}$} & $6,5 \pm 3,2$ & $10,5 \pm 9,5$ & $7,8 \pm 5,6$ & $7.7 \pm 5,7$ & $0.16 \star \star$ \\
\hline \multicolumn{2}{|c|}{$\begin{array}{l}\text { Median number of pigs by breeding } \\
\text { [Median (Interquartile range)] }\end{array}$} & $5(3-10)$ & $12(8-20)$ & $9(4-16)$ & $11.4 \pm 10.6$ & $0.001^{\star \star \star}$ \\
\hline \multirow[t]{4}{*}{$\begin{array}{l}\text { Livestocks } \\
\text { structure }\end{array}$} & reproductive Male & $\begin{array}{l}107 \\
(15)\end{array}$ & $54(13,1)$ & $222(8,7)$ & $\begin{array}{l}383 \\
(10,5)\end{array}$ & \\
\hline & $\begin{array}{l}\text { reproductive } \\
\text { Female }\end{array}$ & $\begin{array}{l}223 \\
(31,3)\end{array}$ & $\begin{array}{l}117 \\
(28,3)\end{array}$ & $\begin{array}{l}733 \\
(28,9)\end{array}$ & $\begin{array}{l}1073 \\
(29,3)\end{array}$ & $<0.001$ \\
\hline & Young pig & $\begin{array}{l}383 \\
(53,7)\end{array}$ & $\begin{array}{l}242 \\
(58,6)\end{array}$ & $\begin{array}{l}1582 \\
(62,3)\end{array}$ & $\begin{array}{l}2207 \\
(60,2)\end{array}$ & \\
\hline & Ratio M:F & $1: 2,0$ & $1: 4,1$ & $1: 3,3$ & $1: 3,2$ & \\
\hline \multirow[t]{3}{*}{ Race } & Locale & $\begin{array}{l}322 \\
(45,2)\end{array}$ & $\begin{array}{l}217 \\
(52,5)\end{array}$ & $\begin{array}{l}2415 \\
(95,2)\end{array}$ & $\begin{array}{l}2954 \\
(80,6)\end{array}$ & \\
\hline & Metis & $\begin{array}{l}386 \\
(54,1)\end{array}$ & $88(21,3)$ & $93(3,7)$ & $\begin{array}{l}567 \\
(15,5)\end{array}$ & $<0.001$ \\
\hline & Other & $5(0,7)$ & $\begin{array}{l}108 \\
(26,2)\end{array}$ & $29(1,1)$ & $142(3,9)$ & \\
\hline \multirow[t]{2}{*}{ Breeding mode } & Enclosure breeding & $\begin{array}{l}45 \\
(62,5)\end{array}$ & $21(80,8)$ & $84(37,7)$ & $\begin{array}{l}150 \\
(46,7)\end{array}$ & \\
\hline & $\begin{array}{l}\text { Permanent } \\
\text { wandering }\end{array}$ & $\begin{array}{l}27 \\
(37,5)\end{array}$ & $5(19,2)$ & $\begin{array}{l}139 \\
(62,3)\end{array}$ & $\begin{array}{l}171 \\
(53,3)\end{array}$ & $<0.001$ \\
\hline
\end{tabular}

* Fisher test exact; ** Kruskal Wallis test; ***

Other (not identified) M (male) F (female)

Table Il: Seroprevalence of anti-cysticercosis antibodies in the herds of the three districts of Dabou, Agboville, Aboisso 


\begin{tabular}{|llll|}
\hline District & Aboisso & Dabou & Agboville \\
\hline N of villages & 10 & 8 & 13 \\
\hline N of farms/herds & 24 & 33 & 59 \\
\hline N total of animals & 387 & 535 & 1614 \\
\hline N of animal sampled & 177 & 194 & 267 \\
\hline N of Positive animals ELISA (\%) & $103(58.1)$ & $74(38.1)$ & $47(17.6)$ \\
\hline N of positive animals WB (\%) & $21(11.9)$ & $37(19.0)$ & $20(7.4)$ \\
\hline N of positive villages (\%) & $7(70)$ & $8(100)$ & $5(23.7)$ \\
\hline N of positive herds $n(\%)$ & $10(41.6)$ & $22(66.0)$ & $14(23.7)$ \\
\hline Prevalence maxi by herd & 33 & 100 & 75 \\
\hline Prevalence min by herd & 0 & 0 & 0 \\
\hline Mean prevalence by herd & 11.8 & 19.0 & 7.4 \\
\hline
\end{tabular}

$\mathrm{N}$ : Number, WB : Western

\section{Figures}




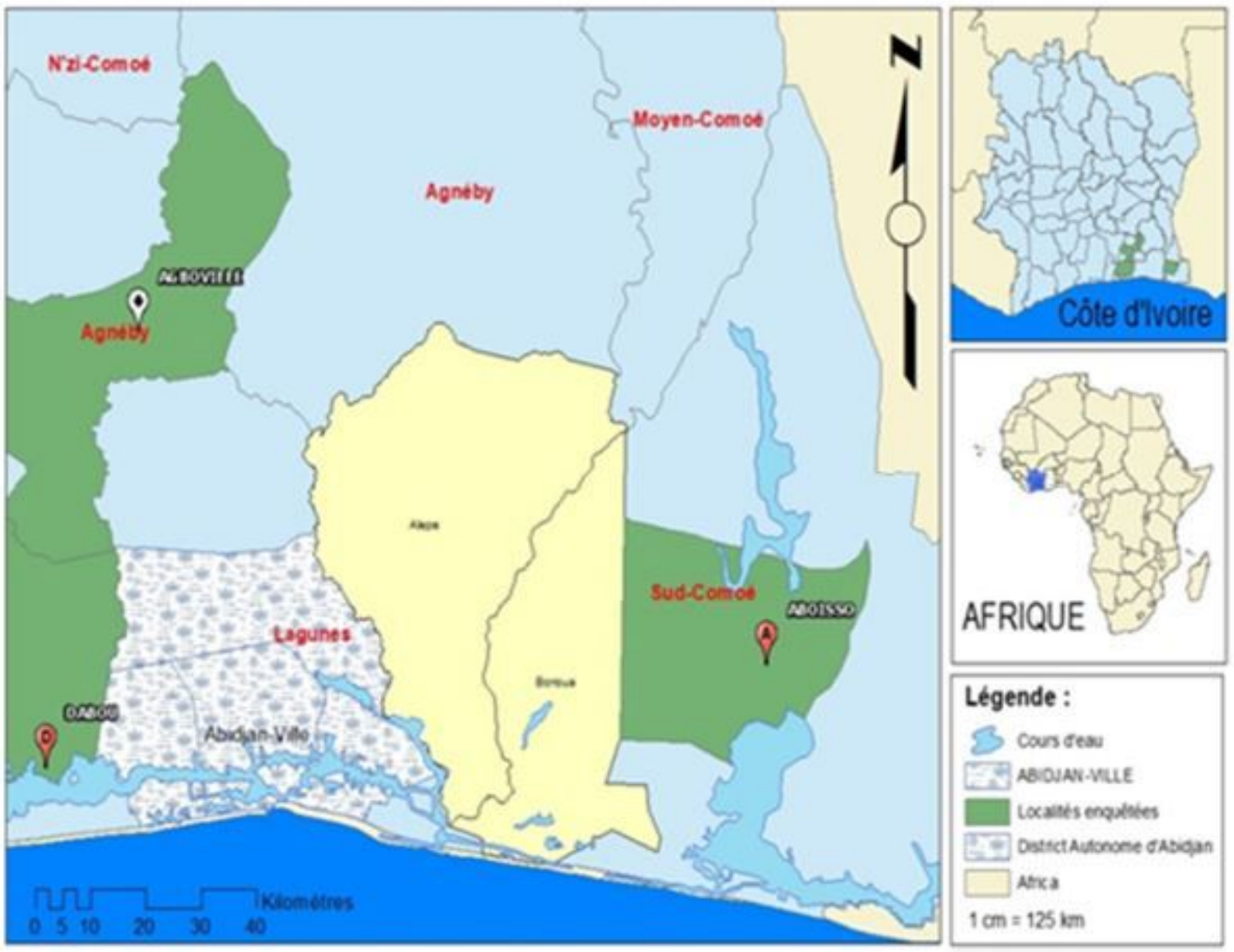

\section{Figure 1}

Map of the study areas 


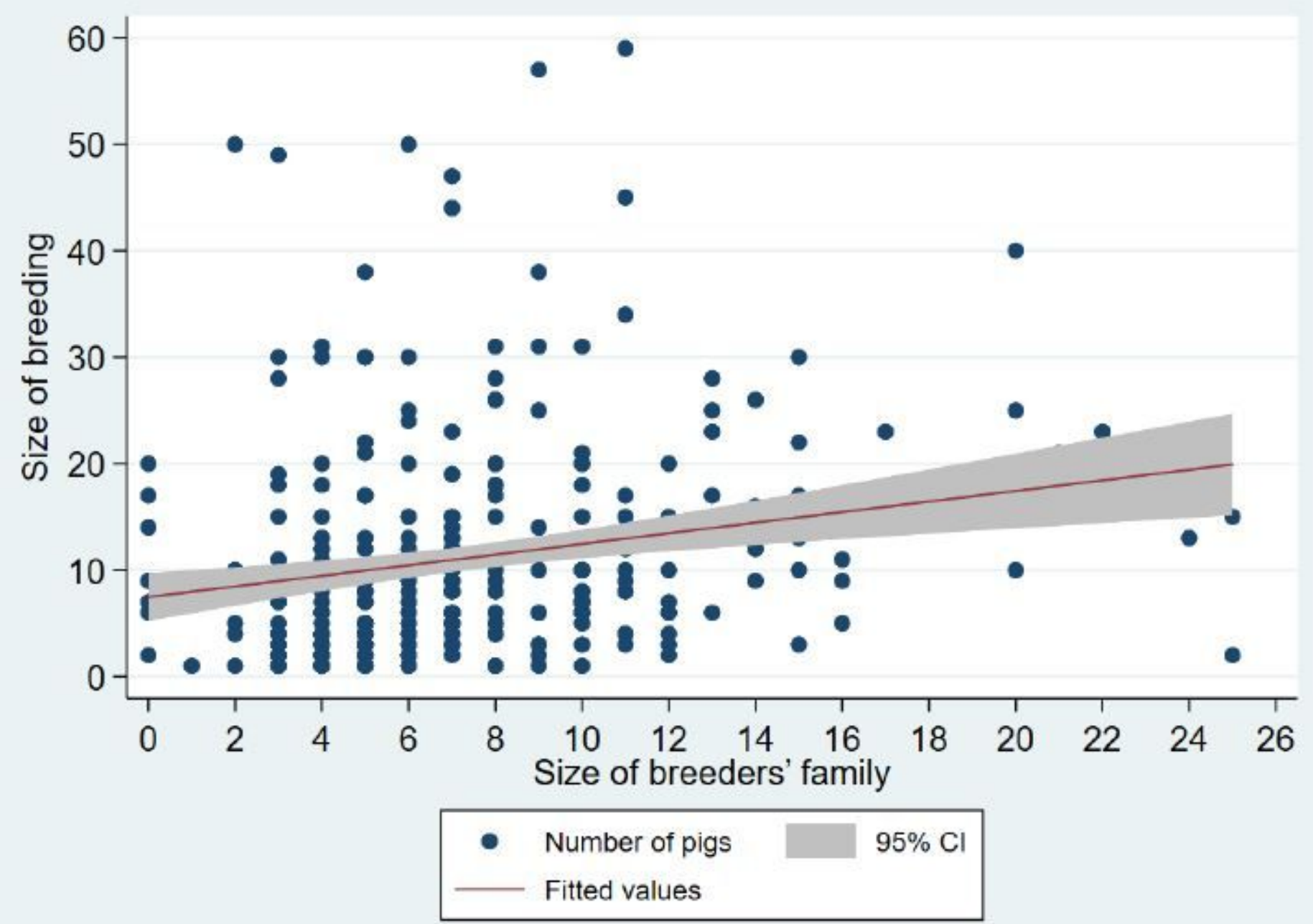

Figure 2

Correlation between the size of the farmer's household and the size of the livestock herd 

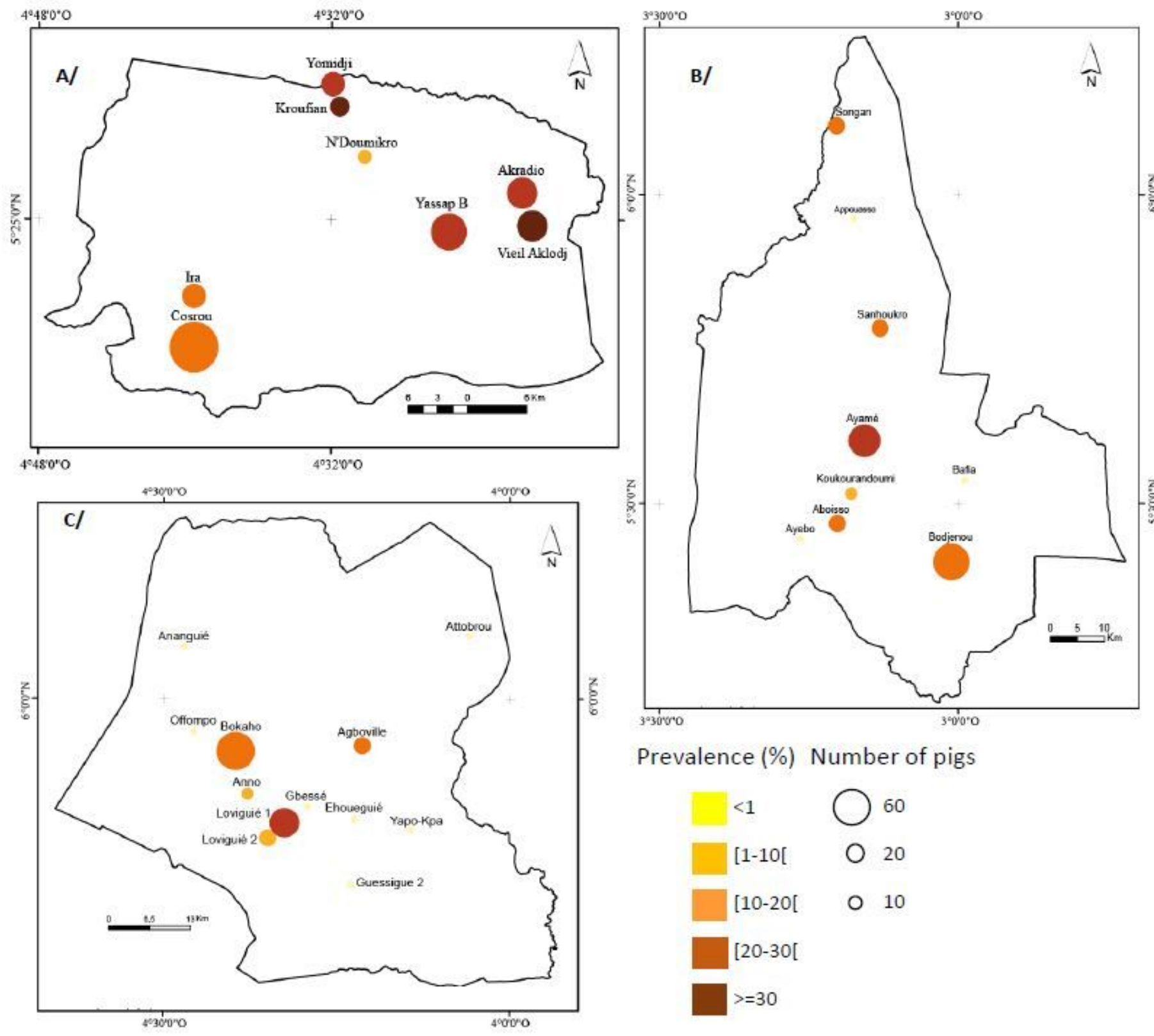

Prevalence (\%) Number of pigs

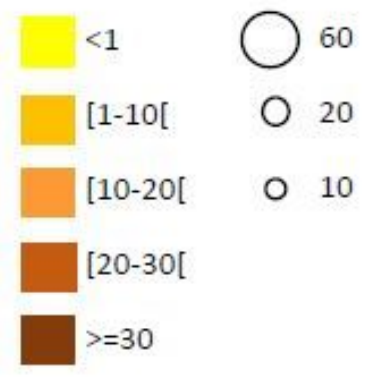

\section{Figure 3}

Prevalence of cysticercosis in the districts of Dabou, Agboville and Aboisso A/ Dabou, B/ Agboville, C/ Aboisso. Size of the circles indicates number of pigs investifgated; color of the circle indicated seroprevalence of ant-cysticercosis antibodies

\section{Supplementary Files}

This is a list of supplementary files associated with this preprint. Click to download.

- ECart1suppldata.doc 